\title{
Effects of Different Nitrogen Fertilizer on Soil Environment and Soil Fertility for Sunlight Greenhouse
}

\author{
G.F. ZHANG \\ Daqing Normal University, Daqing 163712, China
}

\begin{abstract}
In order to investigate the effects of different nitrogen fertilizer on soil environment and soil fertility in sunlight greenhouse, four different types of fertilizer was used in the same amount of nitrogen. The results showed that: (1) soil soluble salt content, EC value, and $\mathrm{pH}$ all increased with the advancing of production process. Different kinds of nitrogen fertilizer affected soil environment and soil fertility in the process; (2) the chemical fertilizer significantly improved soil soluble salt and EC value, calcium nitrate and urea significantly improved soil $\mathrm{pH}$, and the deterioration of soil environment was accelerated. Whereas organic fertilizer or organic manure combine with urea slowed down the changes of soil soluble salt, EC, $\mathrm{pH}$ and the deterioration of soil environment; (3) the application of organic fertilizer, organic fertilizer and urea fertilizer significantly increased the contents of soil organic matter and base dissolving nitrogen, increased the contents of soil available $\mathrm{P}$ and $\mathrm{K}$, and improved soil fertility.
\end{abstract}

KEYWORD: Nitrogen fertilizer; Sunlight greenhouse; Soil environment; Soil fertility

\section{GENERAL INSTRUCTIONS}

Sunlight greenhouse has developed in recent years in China. It has changed environment of crops by using artificial facilities, improved multiple cropping index and increased farmers' income. However, it caused soil salinization due of intensive cultivation, large fertilizing, long-term high temperatures and lack of rain, which restricted its sustainable development. Liu et al. [] found that total salt content of soil in suburb vegetable greenhouses of Harb was 2.1 to 13.4 times higher than in the open field. The soil salinity rose by the increases of shed age. It also showed that continuous cultivation of vegetables and soil salinization will be very clear in Shenyang suburb in three years. The open field rose to $1.56 \mathrm{~g} \mathrm{~kg}^{-1}$ to the average salinity for soil protection in about ten years. The corresponding EC value reached $0.53 \mathrm{mS} \mathrm{cm}{ }^{-1}$, more than crop fertility disorders critical point.

Nitrogen is the largest amount of essential elements for plant growth. It has the largest and most direct effect on crops plant. It takes great significant on quantity of crops. So farmers pursuit of high-yield sidedly, with excess nitrogen fertilizer, partial nitrogen. This phenomenon is serious in greenhouse vegetable production. And it results decreased production efficiently, environmental degradation and soil problems. Previous studies on the impact of greenhouse by fertilization focused on the balanced application of NPK fertilizer. Some study on reducing the amount of fertilizer or application of mitigation physicochemical properties of soil improvers, however studies on different types of soil nitrogen to the environmental impact are less.

We selected different types of nitrogen fertilizer in the experiment and explored its impact on the environment of greenhouse soil and nutrient content. And so we can provide a theoretical basis on rational use of fertilizers in sunlight greenhouse and improve soil environment.

\section{MATERIALS AND METHODS}

\subsection{Test material}

Lactuca sativa $\mathrm{L}$ on test is American fast-growing lettuce, loose leaf variety. The experiment was conducted from September of 2012 to January of 2013 in centers of excellence Greenhouse crops at Ranghulu Lamadian town Daqing City. The soil type was chernozem, and the basic physical and chemical properties are shown in Table 1. 
Table 1.The basic character of soil tested

\begin{tabular}{|c|c|c|c|c|c|c|c|c|}
\hline $\begin{array}{c}\mathrm{TN} \\
\mathrm{g} \mathrm{kg}^{-1}\end{array}$ & $\begin{array}{c}\mathrm{TP} \\
\mathrm{g} \mathrm{kg}^{-1}\end{array}$ & $\begin{array}{c}\mathrm{TK} \\
\mathrm{g} \mathrm{kg}^{-1}\end{array}$ & $\begin{array}{c}\mathrm{AN} \\
\mathrm{mg} \mathrm{kg}\end{array}$ & $\begin{array}{c}\text { Olsen-P } \\
\mathrm{mg} \mathrm{kg}\end{array}$ & $\begin{array}{c}\text { Olsen-K } \\
\mathrm{mg} \mathrm{kg}\end{array}$ & $\begin{array}{c}\text { OM } \\
\mathrm{g} \mathrm{kg}^{-1}\end{array}$ & $\begin{array}{c}\text { Content of soluble } \\
\mathrm{salt}^{-1} \mathrm{~kg}^{-1}\end{array}$ & $\begin{array}{c}\mathrm{EC} \\
\mu \mathrm{s} / \mathrm{cm}^{-1}\end{array}$ \\
\hline 1.243 & 21.45 & 8.65 & 170.30 & 58.45 & 96.80 & 35.46 & $0.916 \mathrm{~b}$ & 7.21 \\
\hline
\end{tabular}

\subsection{Deal with test}

Six treatments were applied and described in Table 2. In addition to the $\mathrm{CK}$, the remaining processing by growth period $30 \mathrm{~g} \mathrm{~m}^{-2}$ net amount of $\mathrm{N}$ fertilizer, basal accounted for $50 \%$, in two days before transplanting into the soil preparation facilities, 20 days after transplanting by $25 \%$ the proportion of dressing for the first time, shift planted 35 days by
$25 \%$ the proportion of a second dressing. Nursery seedling tray, 4 leaf transplanting, spacing $30 \mathrm{~cm}$, spacing $13.3 \mathrm{~cm}$, one seedling per hole. All treatments of phosphorus, potassium was applied at basal-time. And the amount of super phosphate $100 \mathrm{~g}$ $\mathrm{m}^{-2}$, potassium chloride $40 \mathrm{~g} \mathrm{~m}^{-2}$. Each treatment consistent with field management. Residential area of $9 \mathrm{~m}^{2}$, randomized block, repeated three times.

Table 2 way to deal with fertilizer of greenhouse lettuce

\begin{tabular}{|c|l|c|c|c|}
\hline Deal with & Fertilizer & Base fertilizer & First after manuring & Second after manuring \\
\hline A,CK & & 0 & 0 & 0 \\
\hline B & $\mathrm{Ca}\left(\mathrm{NO}_{3}\right)_{2}$ & 15 & 7.5 & 7.5 \\
\hline $\mathrm{C}$ & $\mathrm{CO}\left(\mathrm{NH}_{2}\right)_{2}$ & 15 & 7.5 & 7.5 \\
\hline $\mathrm{D}$ & $\left(\mathrm{NH}_{42} \mathrm{SO}_{4}\right.$ & 15 & 7.5 & 7.5 \\
\hline E & Organic fertilizer & 15 & 7.5 & 7.5 \\
\hline F & $\begin{array}{l}\text { Organic fertilizer (Base fertilizer) } \mathrm{CO}\left(\mathrm{NH}_{2}\right)_{2} \\
\text { (after manuring) combined application }\end{array}$ & 15 & 7.5 & 7.5 \\
\hline
\end{tabular}

Note: the fertilizer counted by Pure $\mathrm{N}$, unit $\mathrm{g} \mathrm{m}^{-2}$

\subsection{Determination of the item and methods}

After the lettuce harvest, took $0-20 \mathrm{~cm}$ topsoil, airdry milled 80 mesh sieve. And then test. Total soluble salts in soil with decolonize water (water and soil ratio of 5: 1) determination of extraction, drying method; conductivity meter assay (soil and water ratio of 5: 1) measurement of soil conductivity; soil acidity $(\mathrm{pH})$ is determined by potential France (soil and water ratio of 2.5: 1) determination; alkaline hydrolysis - soil nitrogen content diffusion assay; molybdenum blue colorimetric determination of soil available phosphorus content; flame photo metric determination of potassium content in soil. Repeat two times for each sample index, taking the average, the data is statistically significant differences in analysis SPSS (16.0) software.

\section{RESULTS AND ANALYSIS}

\subsection{The effect on soil chemical properties for fertilizer treatment}

After a growing season of lettuce, water-soluble salt was higher with no fertilizer treatment (control). The onductivity increase compared to the previous test but no significant difference. PH was significantly improved compared to the previous experiment
(Table 3). These indicated that it is a normal trend with no nitrogen factors interference. It is normal that the accumulation of salt and $\mathrm{pH}$ increase of conductivity.

Measurement of soil water-soluble salt content and EC values, a small increase in organic fertilizer (E), organic fertilizer with urea fertilizer (F) compared to control. But the differences were not significant. On the other hand, values in administering calcium nitrate (B), thiamine (D), urea (C) levels were significantly increased, and significantly higher than $\mathrm{E}$ and $\mathrm{F}$. Thus, greenhouse salinity in soils with the production process is constantly accumulated. Inorganic fertilizer accelerates the accumulation of inorganic fertilizer application rate. The application of organic fertilizers $(E$ and $F)$ is beneficial for slowing the accumulation rate.

The changes of soil $\mathrm{pH}$ after applying fertilizer $\mathrm{i}$ were: $\mathrm{pHs}$ in treatments application of calcium nitrate and urea, increased, and significantly higher than the control or before planting. The $\mathrm{pH}$ in $\mathrm{D}$ was slightly lower than the control (no significant difference), but significantly higher than before planting. In addition, values in $\mathrm{E}$ and $\mathrm{F}$ were significantly lower than the control, but slightly higher than the cultivation $(P>0.05)$. These indicate 
that the application of organic fertilizers (treatments $\mathrm{E}$ and F) could enhance the buffering capacity of the soil solution and effectively improve the soil's $\mathrm{pH}$ environment.

Table 3 different treatment on soil chemical property

\begin{tabular}{|c|c|c|c|}
\hline Deal with & Content of soluble salt g kg-1 & EC1:5, $\mu \mathrm{s} / \mathrm{cm}$ & $\mathrm{pH}$ \\
\hline Before experiment & $0.916 \mathrm{~b}$ & $97.61 \mathrm{c}$ & $7.21 \mathrm{c}$ \\
\hline A, CK & $1.028 \mathrm{~b}$ & $111.81 \mathrm{~b}$ & $7.71 \mathrm{~b}$ \\
\hline B & $1.419 \mathrm{a}$ & $162.48 \mathrm{a}$ & $8.45 \mathrm{a}$ \\
\hline C & $1.333 \mathrm{a}$ & $147.48 \mathrm{a}$ & $8.29 \mathrm{a}$ \\
\hline D & $1.364 \mathrm{a}$ & $156.56 \mathrm{a}$ & $7.64 \mathrm{~b}$ \\
\hline E & $1.066 \mathrm{~b}$ & $117.27 \mathrm{~b}$ & $7.31 \mathrm{c}$ \\
\hline F & $1.034 \mathrm{~b}$ & $119.76 \mathrm{~b}$ & $7.37 \mathrm{c}$ \\
\hline
\end{tabular}

Note: different lowercase in same column shows significantly different treatment $(\mathrm{P}<0.05)$, the below is same.

\subsection{Effect on soil nutrient content after processing offertilizer}

After one growing season, soil organic matter content in no $\mathrm{N}$ fertilizer treatment and application of chemical fertilizer was decreased, and showed as: before the test> no $\mathrm{N}$ fertilizer> application of chemical fertilizer. This indicated that inorganicfertilizer could improve vegetable production and accelerate the consumption of soil organic matter. However, organic fertilizer (E) or organic fertilizer with urea fertilizer $(F)$ obviously improved soil organic matter content. And the increasing effect of $\mathrm{E}$ was most obvious, which increased $8.30 \mathrm{~g} \mathrm{~kg}^{-}(24.3 \%)$ compared with the control, and $7.04 \mathrm{~g} \mathrm{~kg}^{-}(19.9 \%)$ compared with before planting.

Table 4 different treatment on soil nutrient content

\begin{tabular}{|c|c|c|c|c|}
\hline Deal with & $\mathrm{OM} \mathrm{g} \mathrm{kg}^{-1}$ & Basic nitrogen $\mathrm{mg} \mathrm{kg}^{-1}$ & Olsen-P mg kg-1 & Olsen-K mg kg ${ }^{-1}$ \\
\hline Before experiment & $35.46 \mathrm{~b}$ & $170.30 \mathrm{~b}$ & $58.45 \mathrm{a}$ & $96.80 \mathrm{a}$ \\
\hline A & $34.20 \mathrm{~b}$ & $153.22 \mathrm{c}$ & $62.72 \mathrm{a}$ & $102.41 \mathrm{a}$ \\
\hline B & $32.65 \mathrm{~b}$ & $180.73 \mathrm{~b}$ & $61.41 \mathrm{a}$ & $98.72 \mathrm{a}$ \\
\hline $\mathrm{C}$ & $33.07 \mathrm{~b}$ & $177.67 \mathrm{~b}$ & $60.60 \mathrm{a}$ & $97.97 \mathrm{a}$ \\
\hline $\mathrm{D}$ & $32.87 \mathrm{~b}$ & $175.33 \mathrm{~b}$ & $60.25 \mathrm{a}$ & $98.35 \mathrm{a}$ \\
\hline $\mathrm{E}$ & $42.50 \mathrm{a}$ & $213.45 \mathrm{a}$ & $63.63 \mathrm{a}$ & $103.27 \mathrm{a}$ \\
\hline $\mathrm{F}$ & $39.78 \mathrm{a}$ & $201.54 \mathrm{a}$ & $63.08 \mathrm{a}$ & $103.14 \mathrm{a}$ \\
\hline
\end{tabular}

Soil alkali hydrolysable nitrogen content changes as follows: The value in the control (A) was significantly decreased compared with before planting. The organic fertilizer treatment $(\mathrm{E}, \mathrm{F})$ significantly improved the content of soil alkali hydrolysable nitrogen, while application of inorganic nitrogen $(B, C, D)$ slightly increased the nitrogen content. The difference of the contents in the treatments of inorganic fertilizer application was not significant, and the values were shown as: B> C> D. The content in organic fertilizer treatment (E) was the highest among the treatments, which increased $60 \mathrm{mg} \mathrm{kg}^{-1}$ compared with the control, and $43 \mathrm{mg} \mathrm{kg}^{-1}$ compared with before planting.

After one growing season planting, soil available $\mathrm{P}$ and available $\mathrm{K}$ contents for the treatments both increased. The performance of different treatments decreased the order: organic fertilizer $(E$ and $F)>$ No $\mathrm{N}$ fertilizer $(\mathrm{A})>$ inorganic fertilizers $\mathrm{B}, \mathrm{C}$ and $\mathrm{D})>$ before planting. The application of organic fertilizer was beneficial for improving soil $\mathrm{P}, \mathrm{K}$ contents, although the differences among the treatments or compared with before planting were not significant.

\section{DISCUSSIONS}

Surveys and previous studies showed that the protection of soil salt accumulation process will lead to decreased of soil $\mathrm{pH}$. However, the present results showed that after one growing season of lettuce, topsoil $\mathrm{pH}$ value of each treatment increased. The discrepancy could be caused by soil type (alkaline Chernomyrdin). On the other hand, the effect of long-term fertilization need further follow-up survey due to the present study was one-season test.

The most important evaluation for soil salinization is soluble salt content and soil conductivity value, 
which showed a significant positive correlation. Many researchers thought that fertilize applying could increase the soil soluble salt content and conductivity values. This test results were consistent with previous. In addition, the results showed that the increasing rate of the application of organic fertilizers was significantly less than use of chemical fertilizers.

It has shown that nitrogen fertilizer could decrease soil $\mathrm{pH}$, particularly harmonium sulfate was more obvious; and urea could increase soil $\mathrm{pH}$. In this experiment, the application of harmonium sulfate was slightly lower than the control. The urea and calcium nitrate were obviously higher than the control. These were consistent with their predecessors. As to the reason for the existence of differences in fertilizer, the residual $\mathrm{SO}_{4}{ }^{2-}$ ions decreased the soil $\mathrm{pH}$ when most of the harmonium sulfate of $\mathrm{NH}_{4}{ }^{+}$ions may be absorbed . However, the residual $\mathrm{Ca}^{2+}$ ions increase the $\mathrm{pH}$ value when most of $\mathrm{NO}_{3}{ }^{-}$ions in calcium nitrate were absorbed. The soil $\mathrm{pH}$ of application of organic fertilizer significantly lower than the control (no $\mathrm{N}$ fertilizer) may be associated with a strong buffer force concerned.

The test results showed that organic fertilizer (E) or organic fertilizer with urea $(F)$ fertilizer significantly increased the contents of soil organic matter and alkali hydrolysable nitrogen content, and obviously increased the contents of available P and $\mathrm{K}$, which consistent with the previous conclusion. However, inorganic fertilizer reduced soil organic matter, available phosphorus and potassium contents. This may be caused by the increasing of the crop's nutrient absorption with the increasing of fertilizer.

In short, in order to achieve the sustainable production in the sunlight greenhouse, we should consider soil properties, fertilizer characteristics, choice reasonable manure for reducing (slowing) soil degradation, improving soil fertility, and coordination the relationship of ecology, sustainable, efficient to.

\section{ACKNOWLEDGEMENT}

The article is an achievement of the scientific research project in the Education Department of Heilongjiang province, the project number is 12523005.

\section{REFERENCES}

[1] Xu Xiang-feng, Yang Guang-lin, Wang Li-shu, Study on the actuality and development countermeasure of Chinese establishment agriculture. Journal of Northeast Agricultural University, 2005, 36 (4): 520-522

[2] Sun Zhiqiang, Zhang Nan, Zhao Weixing. Effects of $\mathrm{N}$ Application Rates on Yield, Nitrate Accumulation of Lettuce and EC, $\mathrm{pH}$ Value of Soil Acta Agriculturae Jiangxi, 2007, 19 (4): 44-45

[3] Wang Li-ying, Zhang Yan-Cai, Zhai Cai-xia, Effect of balanced fertilization yield and quality of sunlight greenhouse cucumber and soil characteristics under continuous cropping Chinese Journal of Eco-Agriculture, 2008,11 (16): 1375-1383

[4] Li Jie, Ji Jing-Hong, Li Ying. Effect of Different Improvement Measures on Salt Accumulating and Ion Composition of Protected Soil Northern Gardening, 2012 (07): 159-164

[5] Dulian-Feng, Zhang Wei Li, Wushu Xia. Influence of planting age of greenhouse vegetable on soil quality degradation in Yangtse delta area Plant Nutrition and Fertilizer Science, 2006,12 (1): 133-137

[6] Zhang Wenbo. Study on the Effects of the Nitrogen Fertilizer on the Lettuce's Yield and Quality and the Soil's Environment Quality. Henan Agricultural University. 2004

[7] Huangji Chuan, Peng Zhiping, Li Wenying,etc. The Impact of Applying Compost on the Quality of Lettuce, Soil Biological Activity and Soil Fertility CHINESE JOURNAL OF TROPICAL CROPS, 2010, 31 (5): 705710

[8] Liu De, Wu Feng-zhi, Soil salinity status of Monocropping greenhouse in Harbin suburb Northern Horticulture, 1998 (6): 1-2,7

[9] Sharma K L,Uttam Kumar Mandal, Srinivas K. Longterm soil management effects on crop yields and soil quality in a dryland Alfisol. Soil \& TillageResearch.2005

[10] Dawe D, Dobermann A, Ladha J K,et al. Do organic amendments improve yield trends and profitability in intensive rice systems. Field Crops Research. 2003

[11] Fan TL, Wang S Y, Tang X Met al. Grain yieldand water use in a long-termfertilizationtrial in Northwest China Agricultural Water Management. 2005

[12] Yadav R L, Dvivedi BS, Yield trends, and changes in soil organic-C and available NPKin a long-termricewheat system under integrated use of manures and fertilizers. Field Crops Research.2000

[13] Wang Hui, DONG Yuan-hua, Li De-cheng. Nutrient variation in plastic greenhouse soils with the years of cultivation. Soils, 2005, 37 (4): 460-464

[14] Gao Yan-fang, Duan Zeng-qiang, Huan Heng-fu, On physico-chemical properties of Greenhouse Soil in Yixing Region soil, 2007, 39 (6): 968-972

[15] Liu Shou-long, Tong Cheng-li, Wu Jin-shu, Effect of organic manure/chemical fertilizer in fertilization on rice yield under the same N conditon Acta Pedologica Sinica, 2007, 44 (1): 106-112 